\title{
ANALISIS PORTOFOLIO SAHAM DENGAN METODE CAPM DAN MARKOWITZ
}

\author{
Hartiwi Prabowo \\ Management Department, School of Business Management, BINUS University \\ Jln. K. H. Syahdan No. 9, Palmerah, Jakarta Barat 11480 \\ Hartiwi2200@yahoo.com
}

\begin{abstract}
LQ45 index is a row of 45 stocks with the largest commercial transactions in BEI. These stocks are also commonly referred to as blue-chip stocks. Stocks at $L Q 45$ index must meet the criteria and pass a predetermined key. The LQ 45 stocks are continuously being monitored and will be a reviewed for every 6 months (early February and August). Capital Asset Pricing Model (CAPM) is used to estimate the return of a securities, while minimizing the risk to the desired level of returns in stock investing can be done by way of diversification or invest the funds into more than one type of securities (forming portfolios). The purpose of this study was to determine the expected return, and choosing the best stocks to obtain the optimal portfolio composition and profitable to invest. This study uses secondary data, ie data LQ 45, stock prices, the level of available SBI Stock Exchange, BI, and websites. To analyze the data, the writer used method of CAPM and Markowitz Portfolio. The results showed the election of 5 stocks of the most profitable for investors, namely stock UNTR, SMCB, ASII, INDF and BBRI. For companies that issue stocks should interact more with the society and the capital markets to attract more investors.
\end{abstract}

Keywords: CAPM, Markowitz Portfolio, LQ 45

\begin{abstract}
ABSTRAK
Indeks LQ45 adalah kumpulan 45 saham dengan transaksi komersial terbesar di BEI. Saham ini juga sering disebut sebagai saham blue-chip. Saham pada indeks LQ 45 harus memenuhi kriteria dan memenuhi syarat yang telah ditentukan. Saham LQ 45 yang terus menerus dipantau untuk setiap 6 bulan (awal Februari dan Agustus). Capital Asset Pricing Model (CAPM) digunakan untuk memperkirakan return sekuritas, dan meminimalkan risiko ke tingkat yang diinginkan dalam return investasi saham dan bisa dilakukan dengan cara diversifikasi atau berinvestasi dana ke lebih dari satu jenis surat berharga (pembentuk portofolio). Tujuan dari penelitian ini adalah untuk mengetahui hasil yang diharapkan, dan memilih saham terbaik untuk mendapatkan komposisi portofolio optimal dan menguntungkan untuk berinvestasi. Penelitian ini menggunakan data sekunder, yaitu data LQ 45, harga saham, tingkat tersedia Bursa Efek SBI, BI, dan website. Untuk menganalisis data, penulis menggunakan metode CAPM dan Portofolio Markowitz. Dan hasil penelitian menunjukkan pemilihan 5 saham yang paling menguntungkan bagi investor, yaitu saham UNTR, SMCB, ASII, INDF dan BBRI. Dan bagi perusahaan, isu saham harus berinteraksi lebih banyak dengan masyarakat dan pasar modal untuk menarik lebih banyak investor.
\end{abstract}

Kata kunci: CAPM, Markowitz Portfolio, LQ 45 


\section{PENDAHULUAN}

Dalam investasi saham semua investor yang melakukan investasi tentu mengharapkan tingkat pengembalian (return) yang sesuai dengan dana yang diinvestasikan. Namun tingkat pengembalian yang diharapkan oleh investor tidak selalu sesuai dengan tingkat pengembalian aktual yang akan diperoleh sehingga investor tidak mengetahui dengan pasti hasil yang akan diperoleh dari investasi saham. Keadaan ini menunjukkan bahwa investor menghadapi risiko dalam berinvestasi. Oleh karena itu investor harus dapat memperkirakan seberapa besar risiko yang harus ditanggungnya.

Estimasi return suatu sekuritas dengan baik dan mudah memerlukan suatu model estimasi. Capital Asset Pricing Model (CAPM) merupakan salah satu teori yang mencoba menjelaskan bagaimana suatu aktiva ditentukan harganya oleh pasar atau bagaimana menentukan tingkat keuntungan yang dipandang layak untuk suatu investasi saham. Oleh karena itu Capital Asset Pricing Model (CAPM) yang dapat digunakan untuk mengestimasi return suatu sekuritas dianggap penting di bidang keuangan (Purwanti, 2009).

Sedangkan untuk meminimalkan risiko pada tingkat imbal hasil yang dikehendaki dalam berinvestasi saham dapat dilakukan dengan cara diversifikasi atau menanamkan dana ke lebih dari satu jenis surat berharga (membentuk portofolio) (Syamsir, 2004). Namun persoalannya adalah berapa besar proporsi dana harus diinvestasikan pada masing-masing saham agar diperoleh imbal hasil seperti yang dikehendaki dengan risiko yang paling minimum.

Indeks LQ45 adalah deretan 45 saham yang merupakan saham-saham dengan transaksi perdagangan terbanyak di BEI. Menurut Hasnawati (2006), saham-saham ini biasa juga disebut sebagai saham-saham blue-chip. Saham-saham pada indeks LQ 45 harus memenuhi kriteria dan melewati seleksi utama yang telah ditetapkan. Saham-saham yang termasuk didalam LQ 45 terus dipantau dan setiap 6 bulan akan diadakan review (awal Februari dan Agustus).

Mengingat pentingnya melakukan pertimbangan dalam pengambilan keputusan investasi, maka rumusan masalah dalam penelitian ini adalah: bagaimana hasil return yang diharapkan pada masing-masing saham; bagaimana memilih saham terbaik dengan kriteria Coefficient of Variation (CV) minimum; bagaimana mendapatkan komposisi portofolio saham yang optimal; dan manakah saham yang paling menguntungkan untuk berinvestasi. Sedangkan tujuan dari penelitian ini adalah untuk mengetahui hasil yang diharapkan, dan memilih saham terbaik untuk mendapatkan komposisi portofolio optimal dan menguntungkan untuk berinvestasi

\section{Investasi}

Menurut Tandellin (2001), investasi adalah komitmen atas sejumlah dana atau sumber daya lainnya yang dilakukan pada saat ini dengan tujuan memperoleh keuntungan dimasa yang akan datang.

Sedangkan menurut Tjiptono dan Hendy (2001), investasi dapat diartikan sebagai suatu komitmen penempatan dana pada satu atau beberapa objek investasi dengan harapan akan mendapatkan keuntungan di masa mendatang.

\section{Pasar Modal Indonesia}

Pasar modal Indonesia, menurut Jogiyanto (2009) dapat dijelaskan sebagai berikut. Bursa efek (pasar modal) yang terbesar di Indonesia adalah Bursa Efek Jakarta (BEJ) yang juga dikenal dengan nama asingnya sebagai Jakarta Stock Exchange (JSX). Sekuritas yang diperdagangkan di BEJ adalah 
saham preferen (preferred stock), saham biasa (common stock), hak (rights) dan obligasi konvertibel (convertible bonds). Saham biasa mendominasi volume transaksi di BEJ. Bursa efek terbesar setelah BEJ adalah Bursa Efek Surabaya (BES) atau Surabaya Stock Exchange (SSX). Sekuritas yang terdaftar di BEJ juga diperdagangkan di BES. Efektif mulai November 2007, setelah diadakannya RUPSLB (Rapat Umum Pemegang Saham Luar Biasa) yang diadakan pada 30 Oktober 2007, BEJ dan BES bergabung menjadi BEI (Bursa Efek Indonesia).

\section{Saham}

Menurut Darmadji dan Fakhruddin (2001:5), "Saham dapat didefinisikan tanda penyertaan atau kepemilikan seseorang atau badan dalam suatu perusahaan atau perseroan terbatas. Wujud saham adalah selembar kertas yang menerangkan bahwa pemilik kertas tersebut adalah pemilik perusahaan yang menerbitkan surat berharga tersebut. Porsi kepemilikan ditentukan oleh seberapa besar penyertaan yang ditanamkan di perusahaan tersebut.”

Pengertian saham menurut Sawidji (2000:43) "sebagai tanda penyertaan atau pemilikan seseorang atau badan hukum dalam suatu perusahaan. Saham dikenal memiliki karakteristik high riskhigh return. Artinya saham merupakan surat berharga yang memberikan peluang keuntungan yang tinggi namun juga berpotensi risiko tinggi”.

Berikut ini adalah beberapa indeks yang dimiliki BEI berdasarkan pendapat Jogiyanto (2009).

\section{Indeks Harga Saham Gabungan (IHSG)}

IHSG merupakan value-weigthed index, yaitu perhitungannya menggunakan nilai (value) kapitalisasi pasar. IHSG di BEI meliputi pergerakan-pergerakan harga untuk saham biasa dan saham preferen.

\section{Indeks Liquid 45 (ILQ-45)}

Indeks liquid 45 (ILQ-45) dimulai pada tanggal 13 Juni 1994 dan tanggal ini merupakan hari dasar indeks dengan nilai awal 100. Indeks ini dibentuk hanya dari 45 saham-saham yang paling aktif diperdagangkan. Pertimbangan-pertimbangan yang mendasari pemilhan saham yang masuk ILQ-45 adalah liquiditas dan kapitalisasi pasar dengan kriteria sebagai berikut ini: selama 12 bulan terakhir, rata-rata transaksi sahamnya masuk dalam urutan 60 terbesar di pasar regular; selama 12 bulan terakhir, rata-rata nilai kapitalisasi pasarnya masuk dalam urutan 60 terbesar di pasar regular; telah tercatat di BEI paling tidak selama 3 bulan. ILQ-45 diperbaharui tiap 6 bulan sekali, yaitu pada awal Februari dan Agustus.

\section{Jakarta Islamic Index (JII)}

JII dibuat oleh BEI berkerja sama dengan PT. Danareksa Invesment Management. JII menggunakan basis tanggal Januari 1995 dengan nilai awal sebesar 100. JII diperbarui setiap 6 bulan sekali, yaitu pada awal Januari dan Juli. JII merupakan indeks yang berisi dengan 30 saham perusahaan yang memenuhi kriteria investasi berdasarkan Syariah Islam.

\section{Indeks Papan Utama dan Indeks Papan pengembangan}

Pada 8 April 2002, BEI memperkenalkan dua indeks lagi, yaitu Main Board Index (MBX) dan Development Board Index (DBX). Main Board Index (MBX) dimulai dengan 334 saham dan Development Board Index (DBX) dimulai dengan 287 saham. Papan Utama (Main Board) dimaksudkan untuk menampung emiten yang berukuran besar dan mempunyai catatan kinerja yang baik. Papan Pengembangan (Development Board) dimaksudkan untuk penyehatan perusahaan- 
perusahaan yang kinerjanya menurun, perusahaan-perusahaan yang berprospek baik tetapi belum menguntungkan.

\section{Indeks Kompas 100}

Pada 10 Agustus 2007, BEJ (Bursa Efek Jakarta) bekerja sama dengan harian Kompas merilis indeks yang baru yang disebut dengan Indeks Kompas 100. Indeks ini berisi dengan 100 saham yang berkategori mempunyai liquiditas yang baik, kapitalisasi pasar yang tinggi, fundamental yang kuat, serta kinerja perusahaan yang baik.

\section{Capital Asset Pricing Model (CAPM)}

Menurut Keown et al. (2005, p205), definisi dari capital asset pricing model (CAPM) adalah sebagai berikut:

"An equation stating that the expected rate of return on an investment is a function of the risk free rate, the investment's systematic risk, and the expected risk premium for the market portofolio of all risky securities."

\section{Beta}

Menurut Rodoni dan Ali (2010), Beta didefinisikan sebagai alat ukur covariance diharapkan suatu saham dengan portofolio pasar yang terdiversifikasi dengan baik. Sedangkan menurut Jogiyanto (2009), Beta merupakan pengukur risiko sistematik (systematic risk) dari suatu sekuritas atau portofolio relatif terhadap risiko pasar. Beta suatu sekuritas dapat dihitung dengan teknik estimasi yang menggunakan data historis

\section{Coefficient of Variation (CV)}

Menurut Jogiyanto (2009), untuk melakukan analisis investasi, dua faktor harus dipertimbangkan bersama-sama, yaitu return ekspektasian dan risiko aktiva. Koefisien variasi (Coefficient of Variation) dapat digunakan untuk mempertimbangkan dua faktor tersebut bersamaan. Rumus koefisien variasi (Coefficient of Variation) adalah:

$$
C V_{t}=\frac{\text { Ritstike }}{\text { Return Ekspetast }}
$$

Dari rumus koefisien variasi (Coefficient of Variation) dapat diartikan bahwa semakin kecil nilai CV makin baik aktiva tersebut. Makin kecil CV menunjukkan semakin kecil risiko aktiva dan semakin besar return ekspektasinya.

\section{Teori Portofolio Saham}

Menurut Rodoni dan Ali (2010), portofolio merupakan sekumpulan instrument investasi yang dibentuk untuk memenuhi sasaran umum investasi. Portofolio juga dapat diartikan gabungan dari berbagai aktiva/surat-surat berharga/saham/kesempatan investasi.

\section{METODE PENELITIAN}

Jenis penelitian yang digunakan adalah deskriptif, dan time horizone secara cross sectional. Teknik pengumpulan data menggunakan data sekunder berupa harga saham, data IHSG, dan tingkat SBI selama periode Februari 2009 - Januari 2011. Teknik pengambilan sampel dengan cara 
mengambil data dari 19 perusahaan yang masuk dalam Indeks LQ 45 selama 4 periode secara berturut-turut. Penelitian ini menggunakan beberapa metode analisis dalam mencapai tujuan penelitian, yaitu: Capital Asset Pricing Model (CAPM), Coefficient of Variation (CV), Teori Portofolio Model Markowitz.

Tabel 1 Operasional variabel

\begin{tabular}{|c|c|c|c|c|}
\hline Metode & Definisi & Rumus & Variabel & Simbol \\
\hline \multirow{2}{*}{$\begin{array}{l}\text { Coefficient } \\
\text { of } \\
\text { Variation } \\
\text { (CV) }\end{array}$} & \multirow{2}{*}{$\begin{array}{l}\text { rasio deviasi } \\
\text { standar } \\
\text { terhadap rata- } \\
\text { rata hitung }\end{array}$} & \multirow{2}{*}{$C V_{t}=\frac{\text { Fintka }}{R t}$} & $\begin{array}{l}\text { Risiko } \\
\text { (Standar } \\
\text { deviasi) } \\
\end{array}$ & SD \\
\hline & & & $\begin{array}{l}\text { Return } \\
\text { ekspektasi }\end{array}$ & $R i$ \\
\hline \multirow{4}{*}{$\begin{array}{l}\text { Teori } \\
\text { Portofolio } \\
\text { Model } \\
\text { Markowitz }\end{array}$} & \multirow{4}{*}{$\begin{array}{l}\text { Portofolio } \\
\text { yang } \\
\text { dihasilkan } \\
\text { melalui } \\
\text { proses } \\
\text { berdasarkan } \\
\text { mean- } \\
\text { variance }\end{array}$} & \multirow{4}{*}{ 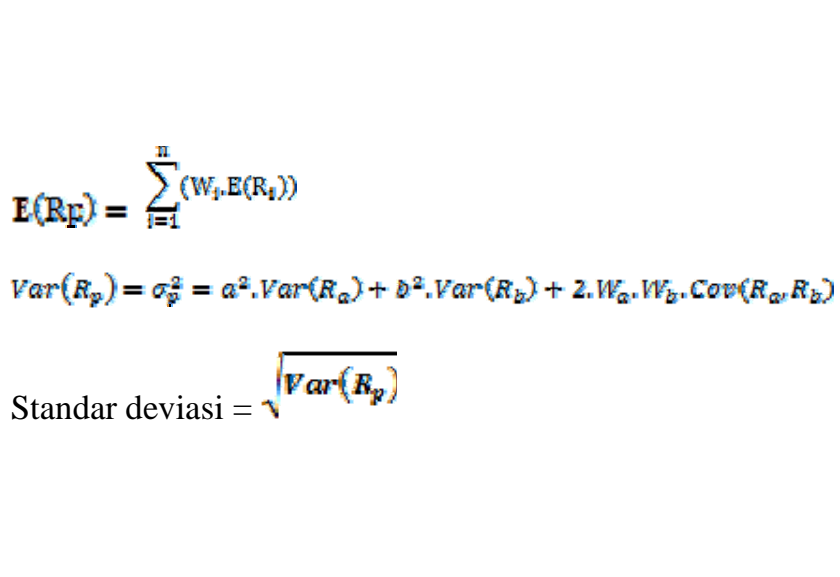 } & $\begin{array}{l}\text { Return } \\
\text { ekspektasian } \\
\text { dari } \\
\text { portofolio }\end{array}$ & $E(\mathrm{Rp})$ \\
\hline & & & $\begin{array}{l}\text { Risiko } \\
\text { portofolio }\end{array}$ & $\begin{array}{l}\operatorname{Var}\left(\mathrm{R}_{\mathrm{p}}\right) \\
\text { atau } \mathrm{o}_{\mathrm{p}}^{2}\end{array}$ \\
\hline & & & $\begin{array}{l}\text { Weight (porsi } \\
\text { di portofolio) }\end{array}$ & $W_{1}$ \\
\hline & & & $\begin{array}{l}\text { Covariance } \\
\text { antar saham }\end{array}$ & $\operatorname{Cov}\left(R_{a}, R_{b}\right)$ \\
\hline \multirow{4}{*}{ САРМ } & \multirow{4}{*}{$\begin{array}{l}\text { Capital Asset } \\
\text { Pricing } \\
\text { Model }\end{array}$} & \multirow{4}{*}{$E\left(R_{t}\right)=R_{f}+\beta_{i}\left(R_{m}-R_{f}\right)$} & $\begin{array}{l}\text { Return } \\
\text { sekuritas ke-i }\end{array}$ & $\mathrm{E}\left(\mathrm{R}_{\mathrm{i}}\right)$ \\
\hline & & & Risk free rate & $R_{f}$ \\
\hline & & & Market Risk & $\mathrm{R}_{\mathrm{m}}$ \\
\hline & & & $\begin{array}{l}\text { Beta sekuritas } \\
\text { ke-i }\end{array}$ & $\beta_{1}$ \\
\hline
\end{tabular}

\section{HASIL DAN PEMBAHASAN}

Pemilihan Saham Berdasarkan 4 Periode (Februari 2009 - Januari 2011) telah diperoleh 19 saham yang tergabung dalam LQ45, yaitu AALI, ADRO, ANTM, ASII, BBCA, BBRI, BDMN, BMRI, INCO, INDF, ISAT, MEDC, PGAS, PTBA, SMCB, TINS, TLKM, UNSP, UNTR.

Perhitungan Return Average dan Standard Deviation

Tabel 2 Return Average dan Standar Deviasi 19 Saham

\begin{tabular}{lrrlll}
\hline Saham & $\begin{array}{c}\text { Return } \\
\text { Saham }\end{array}$ & $\begin{array}{r}\text { Standar } \\
\text { Deviasi }\end{array}$ & Saham & $\begin{array}{c}\text { Return } \\
\text { Saham }\end{array}$ & $\begin{array}{c}\text { Standar } \\
\text { Deviasi }\end{array}$ \\
\hline PTBA & $0,0199 \%$ & $1,9071 \%$ & BBCA & $0,2244 \%$ & $2,4542 \%$ \\
TLKM & - & & & & \\
& $0,0454 \%$ & $1,5927 \%$ & BMRI & $0,2067 \%$ & $2,3506 \%$ \\
AALI & $0,1362 \%$ & $2,3968 \%$ & MEDC & $0,2083 \%$ & $2,5195 \%$ \\
ISAT & $0,1153 \%$ & $1,8482 \%$ & INCO & $0,1385 \%$ & $2,9271 \%$ \\
\hline
\end{tabular}




\begin{tabular}{lcclll}
\hline UNSP & $0,4233 \%$ & $3,2869 \%$ & BDMN & $0,1036 \%$ & $2,6892 \%$ \\
UNTR & $0,4376 \%$ & $1,6870 \%$ & TINS & $0,1039 \%$ & $2,8819 \%$ \\
SMCB & $0,3147 \%$ & $2,3412 \%$ & PGAS & $0,0647 \%$ & $2,0565 \%$ \\
ASII & $0,2830 \%$ & $2,2657 \%$ & ADRO & $0,0651 \%$ & $2,4589 \%$ \\
INDF & $0,2072 \%$ & $1,7872 \%$ & ANTM & $0,0013 \%$ & $2,5193 \%$ \\
BBRI & $0,2094 \%$ & $2,1429 \%$ & & & \\
\hline
\end{tabular}

(Sumber: Hasil Penelitian, 2011)

\section{Hasil Penentuan dan Pengukuran Beta 19 saham}

Beta digunakan dalam mode CAPM untuk menghitung return ekspektasi. Beta itu sendiri merupakan suatu pengukur volatilitas return suatu sekuritas atau return portofolio terhadap return pasar. Dengan kata lain beta adalah pengukur risiko sistematik dari suatu sekuritas atau portofolio relative terhadap risiko pasar. Beta mengelompokkan saham ke dalam tiga kelompok, yaitu: kelompok saham yang memiliki beta $>1$ disebut Saham agresif; kelompok saham yang memiliki beta $<1$ disebut saham lemah; dan kelompok saham yang mempunyai beta $=1$ disebut netral.

Berdasarkan analisis, 95\% dari 19 saham-saham yang telah terpilih memiliki beta lebih besar dari 1. Akan tetapi, terdapat 1 saham yang memiliki beta di bawah 1 yaitu saham UNTR memilik beta sebesar 0,9818. Hal ini berarti saham UNTR disebut saham yang lemah. Sedangkan 18 saham lainnya termasuk saham yang agresif karena memiliki beta lebih besar dari 1. Hal ini karena 18 saham tersebut mengalami kenaikan lebih cepat dari pasar secara keseluruhan dengan situasi pasar sedang menunjukkan gejala bullish (meningkat) dan saham tersebut mengalami penurunan lebih cepat dibandingkan dengan pasar secara keseluruhan dimana pasar dalam keadaan bearish (menurun).

\section{Hasil Perhitungan CAPM}

Tabel 3 Daftar Hasil E( ～） 19 Saham

\begin{tabular}{clrll}
\hline No & Saham & E( ) & Return & Kesimpulan \\
\hline 1 & AALI & $-0,0408$ & $-0,0014$ & Undervalued \\
2 & ADRO & $-0,0392$ & 0,0007 & Undervalued \\
3 & ANTM & $-0,0477$ & 0,0000 & Undervalued \\
4 & ASII & $-0,0347$ & 0,0028 & Undervalued \\
5 & BBCA & $-0,0332$ & 0,0022 & Undervalued \\
6 & BBRI & $-0,0884$ & 0,0021 & Undervalued \\
7 & BDMN & $-0,0468$ & 0,0010 & Undervalued \\
8 & BMRI & $-0,0359$ & 0,0021 & Undervalued \\
9 & INCO & $-0,0682$ & 0,0014 & Undervalued \\
10 & INDF & $-0,0135$ & 0,0021 & Undervalued \\
11 & ISAT & $-0,0103$ & $-0,0012$ & Undervalued \\
12 & MEDC & $-0,0449$ & 0,0021 & Undervalued \\
13 & PGAS & $-0,0272$ & 0,0006 & Undervalued \\
14 & PTBA & $-0,0179$ & $-0,0002$ & Undervalued \\
15 & SMCB & $-0,0336$ & 0,0031 & Undervalued \\
16 & TINS & $-0,0625$ & 0,0010 & Undervalued \\
\hline
\end{tabular}




\begin{tabular}{lllll}
\hline 17 & TLKM & $-0,0015$ & $-0,0005$ & Undervalued \\
18 & UNSP & $-0,1137$ & $-0,0042$ & Undervalued \\
19 & UNTR & 0,0024 & 0,0044 & Undervalued \\
\hline
\end{tabular}

Sumber: Hasil Penelitian, 2011

Dapat dilihat pada tabel di atas, semua saham memiliki kesimpulan undervalued karena nilai return yang diharapkan berada di bawah nilai return saham masing-masing. Maka berdasarkan hasil perhitungan CAPM, hasil yang dapat disimpulkan adalah harga saham pada masing-masing 19 saham tergolong murah, karena return yang diharapkan lebih kecil dari return yang diperoleh.

Langkah selanjutnya penyeleksian Saham untuk Portofolio, dengan Perhitungan CV (Coefficient of Variation). Berdasarkan hasil perhitungan return average dari 19 saham tersebut ratarata memiliki return yang bernilai positif, namun terdapat beberapa saham yang memiliki return negatif, yaitu PTBA (-0,0199\%), TLKM (-0,0454\%), AALI (-0,1362\%), ISAT (-0,1153\%), dan UNSP $(-0,4233 \%)$. Kemudian saham-saham yang memiliki return negatif tersebut tidak dimasukkan ke dalam penyeleksian berikutnya. Kemudian penulis memilih 10 saham teratas dari peringkat yang nantinya akan dimasukan portofolio. Peringkat yang dibuat berdasarkan CV paling kecil. Yakni : UNTR, SMCB, ASII, INDF, BBRI, BBCA, BMRI, MEDC, INCO, BDMN.

\section{Portofolio Diversifikasi dengan Teori Markowitz}

Saham-saham yang telah terpilih berdasarkan CV tersebut kemudian diuji korelasi dari tiaptiap saham tersebut. Koefisien korelasi menunjukkan besarnya hubungan pergerakan antara dua saham relatif terhadap masing-masing deviasinya. Nilai dari koefisien korelasi berkisar dari +1 sampai dengan -1 .

Selanjutnya yang harus dilakukan setelah mendapatkan data korelasi antar 10 saham tersebut, adalah melakukan kalkulasi untuk mencari nilai covariance dari tiap saham dengan saham yang lain, covariance dapat dihitung dengan melakukan perkalian antara nilai korelasi yang didapat sebelumnya dengan standard deviation saham tersebut.

\section{Portofolio 10 Saham}

Setelah mendapatkan nilai covariance, selanjutnya menentukan alokasi saham sementara untuk menghitung return portofolio dan risiko portofolio yaitu dengan menentukan weight tiap-tiap saham sebagai kadar proporsi portofolio. Sepuluh saham tersebut dibagi weight-nya secara rata sebesar $10 \%$ untuk setiap saham.

Setelah mendapatkan hasil dari portofolio 10 saham, maka penulis melakukan perbandingan dengan membuat portofolio 5 saham yang weight-nya juga dibagi sama rata. Lima saham ini dipilih juga berdasarkan CV. Dalam menganalisis portofolio 5 saham ini, tahap-tahap yang dilakukan penulis sama dengan saat menganalisis portofolio 10 saham.

\section{Optimalisasi Portofolio 5 Saham}

Setelah mendapatkan kesimpulan bahwa portofolio 5 saham lebih menguntungkan daripada portofolio 10 saham, kemudian penulis melakukan optimalisasi portofolio 5 saham dengan menghitung kemungkinan-kemungkinan yang dapat terjadi untuk mendapatkan komposisi-komposisi portofolio yang terbaik. Penulis mengasumsikan kemungkinan yang terjadi pada pembobotan berupa weight minimal $10 \%$ dan weight memiliki nilai kelipatan dari $10 \%$, dengan weight dari 5 saham tersebut jika dijumlahkan bernilai $100 \%$. Setelah melakukan perhitungan akan kemungkinan- 
kemungkinan yang ada, penulis mendapatkan 120 portofolio dengan komposisi yang berbeda-beda. Kemudian berdasarkan 120 portofolio tersebut terdapat 3 portofolio optimal, yaitu berdasarkan return tertinggi terdapat pada portofolio ke-2, berdasarkan risiko terkecil terdapat pada portofolio ke-29, dan berdasarkan CV terkecil terdapat pada portofolio ke-9.

\section{Saham yang Paling Menguntungkan}

Tabel 4 Daftar Saham yang Paling Menguntungkan

\begin{tabular}{llll}
\hline Saham & \multicolumn{1}{c}{ Nama Perusahaan } & \multicolumn{1}{c}{ Jenis Industri } & \multicolumn{1}{c}{ Status } \\
\hline UNTR & United Tractors Tbk. & Perdagangan, Jasa dan Investasi & Undervalued \\
SMCB & Holcim Indonesia Tbk. & Industri Dasar dan Kimia & Undervalued \\
ASII & Astra Internasional Tbk. & Aneka Industri & Undervalued \\
INDF & Indofood Sukses Makmur Tbk. & Industri Bahan Konsumsi & Undervalued \\
BBRI & Bank Rakyat Indonesia Tbk. & Keuangan & Undervalued \\
\hline
\end{tabular}

(Sumber: Hasil Penelitian, 2011)

\section{Implikasi}

Pada dasarnya terdapat 3 jalan untuk mendapatkan saham, yaitu: membeli saham di pasar perdana atau ketika sebuah perusahaan melakukan penawaran umum (go public); membeli saham di pasar sekunder atau membeli saham yang telah tercatat dan diperdagangkan di Bursa Efek. Khusus untuk di pasar sekunder, terlebih dahulu kita harus menjadi nasabah di salah satu broker saham atau perusahaan sekuritas yang menjadi anggota di Bursa Efek; membeli saham melalui pembelian unit penyertaan Reksa Dana (melalui Reksa Dana).

Bagi investor, khususnya investor yang memilih jalan kedua yaitu membeli saham di pasar sekunder melalui broker, 5 saham yang paling menguntungkan di atas dapat dijadikan suatu pilihan alternatif untuk bernvestasi saham. Karena saham-saham tersebut merupakan hasil penyeleksian terbaik, seperti yang telah dijelaskan di atas.

Sedangkan untuk perusahaan yang mengeluarkan saham agar return sahamnya baik sehingga diminati oleh investor terdapat beberapa cara, salah satunya yaitu dengan melakukan banyak interaksi dengan masyarakat dan dengan pasar modal. Dengan kata lain, perusahaan harus terbuka. Hal ini dapat menumbuhkan rasa kepercayaan investor terhadap perusahaan tersebut. Salah satu cara perusahaan berinteraksi, yaitu dengan mengadakan public expose.

\section{SIMPULAN}

Simpulan yang diperoleh dari penelitian ini adalah sebagai berikut. Berdasarkan analisis CAPM, return yang diharapkan pada masing-masing 19 saham memiliki nilai di bawah return yang diperoleh dari masing-masing saham tersebut. Hal ini berarti 19 saham tersebut memiliki harga yang murah. Berdasarkan peringkat Coefficient Of Variation (CV), terpilih 10 saham: yaitu: UNTR, SMCB, ASII, INDF), BBRI, BBCA, BMRI , MEDC , INCO, dan BDMN.

Penerapan teori Markowitz, dengan menggunakan data closing price harian dari setiap saham saringan Coefficient of Variation (CV) menghasilkan 3 portofolio optimal, yaitu portofolio optimal berdasarkan return terbesar, berdasarkan risiko terkecil, dan berdasarkan CV (Coefficient of Variation) 
terkecil. (a) Portofolio dengan return terbesar terdapat pada portofolio kedua, dengan komposisi: saham UNTR , SMCB , ASII , INDF , BBRI . Portofolio ini memiliki return sebesar, dengan risiko sebesar 1,0773\%, serta menghasilkan CV sebesar 2,9599. Portofolio ini cocok untuk investor yang memiliki tipe aggressive. (b) Portofolio dengan risiko terkecil terdapat pada portofolio ke-29, dengan komposisi: saham UNTR, SMCB, ASII, INDF, BBRI. Portofolio ini memiliki return sebesar 0,3027\%, dengan risiko sebesar 0,8831\%, serta menghasilkan CV sebesar 2,9177. Portofolio ini cocok untuk investor yang memiliki tipe defensive dan investor tipe conservative. (c) Portofolio dengan CV (Coefficient of Variation) terkecil terdapat pada portofolio kesembilan, dengan komposisi: saham UNTR, SMCB, ASII, INDF, BBRI. Portofolio ini memiliki return sebesar 0,3286\%, dengan risiko sebesar 0,9229\%, serta menghasilkan CV sebesar 2,8082. Portofolio ini cocok untuk investor yang memiliki tipe balanced dan tipe moderately aggressive.

Berdasarkan analisis CAPM dan Portofolio Markowitz yang telah dilakukan, maka saham yang paling menguntungkan untuk berinvestasi adalah saham UNTR, SMCB, ASII, INDF dan BBRI.

\section{DAFTAR PUSTAKA}

Darmadji, T., dan Fakhruddin, M. (2001). Pasar Modal di Indonesia: Pendekatan Tanya Jawab. Jakarta: Salemba Emban Patria.

Fabozzi, F. J. (2000). Manajemen Investasi. Buku Satu. Jakarta: Salemba Empat.

Hasnawati, S. (2006). Penilaian Saham, Memahami Cara Berinvestasi Saham di Pasar Modal. Jurnal Bisnis \& Manajemen. Volume 2 No. 3 Mei 2006 hal 213-237. http://lemlit.unila.ac.id/file/JURNAL\%20Bisnis\%20dan\%20Manajemen\%20(JBM).p df. 10 Juni 2010.

Husnan, S., dan Pudjiastuti, E. (2004). Dasar-dasar Manajemen Keuangan. Edisi keempat. Yogyakarta: AMP YKPN.

Jogiyanto, H. (2009). Teori Portofolio dan Analisis Investasi. Edisi Keenam. Yogyakarta: BPFE.

Keown, A. J., Martin J. D., Petty J. W., \& Scott D. F. (2005). Financial Management: Principles and Applications. $10^{\text {th }}$ ed. New Jersey: Pearson Prentice Hall.

Purwanti, D. (2009). Simulasi Lindung Nilai Portofolio dengan Mini LQ Futures Periode 1 Agustus, 28 November 2008. Tesis tidak dipublikasikan. Jakarta: Universitas Bina Nusantara.

Rodoni, A., dan Ali, H. (2010). Manajemen Keuangan. Jakarta: Mitra Wacana Media.

Rodoni, A., dan Othman Yong (2002). Analisis Investasi dan Teori Portfolio. Jakarta: Raja Grafindo Persada.

Sawidji, W. (2000). Cara Sehat Investasi di Pasar Modal. Edisi 2000. Jakarta: Yayasan MPU Ajar Artha. 
Syamsir, H. (2004). Solusi Investasi di Bursa Saham Indonesia: Pendekatan Analisis Teknikal melalui Studi Kasus Riil dengan Dilengkapi Formulasi MetaStock. Jakarta: Elex Media Komputindo.

Tandelilin, E. (2001). Analisis dan Manajemen Portofolio. Edisi Pertama. Yogyakarta: BPFE.

Tjiptono, D., \& Hendy, M. F. (2001). Pasar Modal Di Indonesia: Pendekatan Tanya jawab. Jakarta: Salemba Empat.

Weygandt, J., Kieso, D., \& Kimmel, P. (2005). Accounting Principles. $7^{\text {th }}$ ed. New York: John Wiley \& Sons. 